\title{
American Sign Language, Peer Play, and the Deaf Child: A Case Study of Ann
}

\author{
Millicent Musyoka \\ Lamar University, Beaumont, USA \\ Email:mmusyoka@lamar.edu
}

Received 16 September 2015; accepted 2 November 2015; published 5 November 2015

Copyright (C) 2015 by author and Scientific Research Publishing Inc.

This work is licensed under the Creative Commons Attribution International License (CC BY). http://creativecommons.org/licenses/by/4.0/

c) (i) Open Access

\begin{abstract}
Play provides signing deaf children with the opportunity to communicate and interact with peers while they use and develop conversation skills or extended discourse in American Sign Language (ASL) (Musyoka, 2015). The goal of this study is to examine how play supports thinking, imagination, social, language and literacy development. To analyze the effectiveness of play, the researcher investigated how one deaf child, Ann used her ASL with various play partners in different play centers set up by the teacher in a preschool classroom that followed the ASL/English bilingual philosophy.
\end{abstract}

\section{Keywords}

Play, Play Partner, American Sign Language, Deaf Children

\section{Introduction}

The ability to use language during peer play provides opportunities for children to engage in more complex play interactions. Also, language use during peer play provides opportunities for easily acquiring language routines. Hence, it is important to understand the language used between children and their peers. Aukrust (2004) investigated explanatory discourse in peer play talk. Aukrust identified three types of explanatory discourse in peer play conversations: spontaneous explanations, responsive explanations, and explanatory requests. Spontaneous explanations referred to how the child gave an explanation without a request from another peer. With responsive explanations, the child responded to a request or proposal by giving explanations. Lastly, with explanatory requests, the child is directly asked for an explanation. Spontaneous explanations were noted to be the most frequently found aspect of peer conversation over all other types of explanatory discourse.

Play partners are reported to influence the nature of play behavior, interactions and conversations (Doyle, Connolly, \& Rivest, 1980; Hoff, 2010, 2003; Musyoka, 2015). Friendship in children’s play is determined by observing children during play to see with whom they played (Marshall \& McCandless, 1957; Ramsey, 1995). 
Doyle et al. (1980) and Musyoka (2015) stress that peer familiarity has impact on the child's social interaction and cognitive level of play. They observed that in the presence of a familiar friend, the child demonstrated more social interactions and higher cognitive level of play. Preschool aged children are aware of individual differences in the quality and quantity of social behavior (Marshall \& McCandless, 1957) and this awareness may influence their play behavior, play interaction and language use. A recent study of a deaf child's play behaviors showed that play behavior varied depending on the characteristics of the play partner (Musyoka, 2015). For example, Musyoka (2015) observed that a child with more close relationship with a play partner engaged in more complex social and cognitive play behaviors compared to a child with less familiarity with a play partner.

Previous studies have also shown that language use varies with conversational partners. Hoff (2010) investigated young children's interaction with three different conversational partners: a 5-year-old sibling, an 8-yearold older sibling, and their mother. She observed that the children's use of vocabulary and responses to questions varied across the conversational partners with the children using more complex language structures with the mother. These findings concur with Shatz and Gelman's (1973) work on how children's language use varies as they shift from one conversational partner to another. In Shatz and Gelman's (1973) study of 4-year-old children, it was found that children used more complex speech when talking to an adult than when talking to a 2-year-old.

Research has shown that teachers integrate play into their classroom learning and teaching through the use of play centers as avenues to scaffold or support language development and learning. Previous work showed that extended discourse, and pretend talk that occur during play umpire language skills, can be used to support literacy development (Dickinson \& Tabors, 2001; Roskos \& Christie, 2000). Previous research has also shown the importance of supporting children's natural use of various language functions to develop metalinguistic awareness and comprehensions of language of texts (Pershey, 1994, 1997). Metalinguistic awareness refers to the child's ability to think about language and talk about it.

Deaf children acquire language at widely varying developmental stages. Research shows that visual language is more accessible to deaf children as it provides them with language they can understand or comprehensible language input (Kuntze 1998; Gerner de Garcia, 2003; Morford \& Mayberry 2000). There are a number of deaf children with deaf signing parents who provide a visual language to their deaf child from birth. As a result, their language development is similar to the language development of their hearing peers (Allen, 1986; Mitchell \& Karchmer, 2004, 2005; Morford, \& Mayberry. 2000; Newport \& Meier, 1985; Woolfe et al., 2010). However, most deaf children do not gain are not exposed to a visual language or signing so they cannot access comprehensible language input until well after birth, much later in early or late childhood or even during adolescence and young adulthood (Johnson, Liddell, \& Erting, 1989; Lederberg \& Spencer, 2001; Mitchell \& Karchmer 2004, 2005). Previous studies have shown that many deaf children arrive in preschool classrooms without competence in a native language. They come from homes with deprived language access (Erting, 2003; Free et al, 2011; Johnson, Liddell, \& Erting, 1989; Kuntze, 1998; Moores, 2001) and such variations in language access have impacted their cognitive, linguistic, and social development as well (Mayberry, 2002; Schick, de Villiers \& de Villier, 2002; Schick, de Villiers, de Villier, \& Hoffmeister, 2007; Mahshie, 1997).

Language access is critical for deaf children's social interactions including play interactions and these early interchanges between mother and child should come early (Meadow, Greenberg, Erting, \& Carmichael, 1981; Spencer 1993, 1996, 2000). Previous research neglected attention to language but instead focused on communication modes: oral speech, lip-reading, Total Communication, English Signing Systems or other forms of manual signals (Brackett \& Henniges, 1976; Darbyshire, 1977; Cornellius \& Hornett, 1990; Esposito \& Koorland, 1989; Gatty, 1990; Gregory \& Mogford, 1983; Higginbotham \& Baker, 1981; Krestchmer, 1972; Mann, 1984; Schirmer 1989). These studies did not address how deaf children learn to play using their American Sign Language (ASL).

What previous studies did focus on was the nonlinguistic means to communicate rather than focusing on the use of language during play activities (Yoshinaga-Itano \& Stredler-Brown, 1992). Also, these researchers indicated deaf children were less socially interactive with limited or no use of language, compared to their hearing peers. It is important to note that these studies did not focus on deaf children who have access to a comprehensible visual language input, which is ASL, both at home and school. Hence, to broaden our understanding of how young deaf children who use ASL play and interact with their peers, this study was undertaken to fill this gap in the literature. 


\section{Theoretical Framework}

Utilizing Michael Halliday’s language functions as a theoretical framework, The researcher investigated how one deaf girl used sign language with her peers during play (Halliday, 1974, 1975, 1978). Halliday studied young children's language from a functional-interactional perspective. He observed his son's interaction with his mother. He noted that a young child tended to use language one function at a time, while an adult integrated all language functions (Halliday, 1974). Halliday’s seven language functions used in this study are shown in Table 1.

According to Halliday, these functions are developmental and acquisition during the first two years of life. The seven language functions have been observed to proceed from instrumental language (satisfy wants) to the informational language (exchange information/ideas with others) or heuristic language (ask questions) (Halliday, 1979; Carpenter, Mastergeorge, \& Coggins, 1983; Olswang, Stoel-Gammon, Coggins, \& Carpenter, 1987).

The central question addressed in this study is "What is the nature of language use by a native ASL deaf child during peer play?

The sub questions are:

1) Does a native ASL deaf child demonstrate the ability to use language with play partners in an ASL/English bilingual classroom?

2) Does a native ASL deaf child use of language vary with different play partners?

3) Does play context influence a native ASL deaf child's use of language with play partners?

\section{Methodology}

\subsection{Data Collections}

The data from the current study was collected from ten-play centers set up by a preschool teacher for her students. The data collection focused on one of the students, Ann. Ann's use of language with peers was observed, coded and analyzed during a one-year period. The dataset selected and used in this study was that of Ann, collected from the time she was 4 years until 5 years of age. The data was collected in one academic year during the fall and spring semester.

\subsection{Participant}

A four-year-old native ASL, deaf child named Ann, was observed while she engaged in play with peers in ten play centers set in a preschool classroom. Ann is a fourth generation deaf child with deaf parents and deaf siblings. The criterion used to select the participant included:

1) A native-deaf user of ASL,

2) Attended an ASL/English bilingual preschool program, and,

3) The deaf child with no additional identified disabilities.

Table 1. Halliday’s language functions.

\begin{tabular}{lll}
\hline Language Function & Function description & Example \\
\hline Instrumental: & $\begin{array}{l}\text { The child uses language to get things done, attending to personal } \\
\text { needs and serve the function of "I want". }\end{array}$ & I want play dough \\
Language is used to control the behavior of others, to make them & Please stop \\
do things you want. & $\begin{array}{l}\text { Language is used to define, initiate and exercise interactions } \\
\text { between self and others }\end{array}$ & Do you mind I play with you? \\
Interactional model & $\begin{array}{l}\text { Language is used to express awareness of self, and assert personal } \\
\text { preferences }\end{array}$ & My shirt is blue \\
Personal & $\begin{array}{l}\text { Language is used to explore, acquire information, and learn about } \\
\text { the environment. }\end{array}$ & Who is that? \\
Heuristic: & $\begin{array}{l}\text { Language is used to create an imaginary environment, tell stories, } \\
\text { pretend play, or exploring one's own imagination }\end{array}$ & The baby is sleeping now. \\
Imaginative & Language is used to transmit or exchange information to others. & Tomorrow I will not come to school \\
Informative &
\end{tabular}




\subsection{Play Partners}

Ann's peers included 12 children in her preschool classroom. Of these 12 children, 8 children had Deaf parents. Of the 8 children who had Deaf parents, three had both parents being Deaf and their families were reported to be actively involved in the Deaf community. Ann demonstrated more social interactions with these three peers in and out of school. According to teacher's evaluation report on the three peer's language ability, they performed similar to Ann and were considered to be Ann's language peers. These three peers included Jean, Barbara and Carol and are referred as Friends in this study. The three friends are Deaf native ASL users. The rest of the peers in the class are referred as Other Peers. In addition, the other five children who had deaf parents had lower language scores compared to Ann on teachers' language evaluation reports. Two of these five children had only one deaf parent and had no deaf siblings.

\subsection{Play Context in the Classroom}

The study focused on indoor play that occurred in one ASL/English bilingual preschool classroom. An ASL/ English bilingual preschool classroom uses both ASL and English as the language of instruction. The classroom was organized into play centers. During the one year in which this data was collected the teacher set up 10 play centers. The play centers included Lego play center, play dough center, dramatic play center, playing cards center, rice play center, farm animal play center, mini block play center, large block play center, geo boards center, and puzzle centers. Each day the teacher set up 3 - 4 play centers. The teachers decided which play center were available and assigned the children to the various play centers.

\subsection{Data Analysis}

Ann's use of language with peers was observed, coded and analyzed in a total of 22 selected play episodes during a one-year period. The criterion used to select the play episodes was based on time she engaged in the play. Play episodes included in the data analysis are those of Ann's play that lasted 10 minutes or more. To code and analyze language, each of Ann's utterances in 22 play episodes in ten play centers were categorized based on Halliday's (1974) seven language functions. In this study, an utterance was defined as a conversational unit separated by either interruptions or pauses (Wiens, Molde, Holman, \& Matarazzo, 1966). According to Wiens and colleague "The utterance is separated at either end by two silence periods-one silence following the other participant's last comment (that is the speaker's latency), the second silence following the speaker's own comment and preceding the listener's next comment (that is the listener's latency)” (Wiens et al, 1966: p. 253). In addition to the manual signs and fingerspelling, non-manual signals, including use of gestures, facial expression and body movement were included as part of the conversational unit and also noted as part of the language. The intercoder reliability process involved two ASL users, one native and the other non-native. The goal of inter- coder reliability is to assess the degree to which codings by multiple coders are similar. According to Miles and Huberman (1994), the use of a systematic coding process by each coder is more reliable compared to each coder using own or individual coding process. In this study the use of a codebook provided high interrcoder reliability (Miles \& Huberman, 1994). The native user served as the peer reviewer in this entire study. The process involved glossing of the ASL utterance, creating a coding system, coding, reviewing the coding system, coding decision making and final coding. Glossing means writing one language in another. In this study it meant writing ASL in English. This process was repetitive with researchers and coders meeting weekly to discuss the data.

\section{Findings}

Three research questions were designed to address this question.

Research Question 1: Does a native ASL Deaf child demonstrate the ability to use language with play partners in an ASL/English bilingual classroom?

The first research questions focused on how Ann used language for various functions with play partners over the one-year timeframe. Ann used all seven-language functions in her conversations (see Figure 1).

In Figure 1, the data shows high percentages of interactional language function (32.8\%), regulatory language function (22.6\%) and informative language function (17.5\%). In comparison, Ann's language use indicated low percentages of heuristic language function (3.9\%) instrumental language function (6.7\%), imaginative language function (7.9\%) and personal language function (8.6\%). 


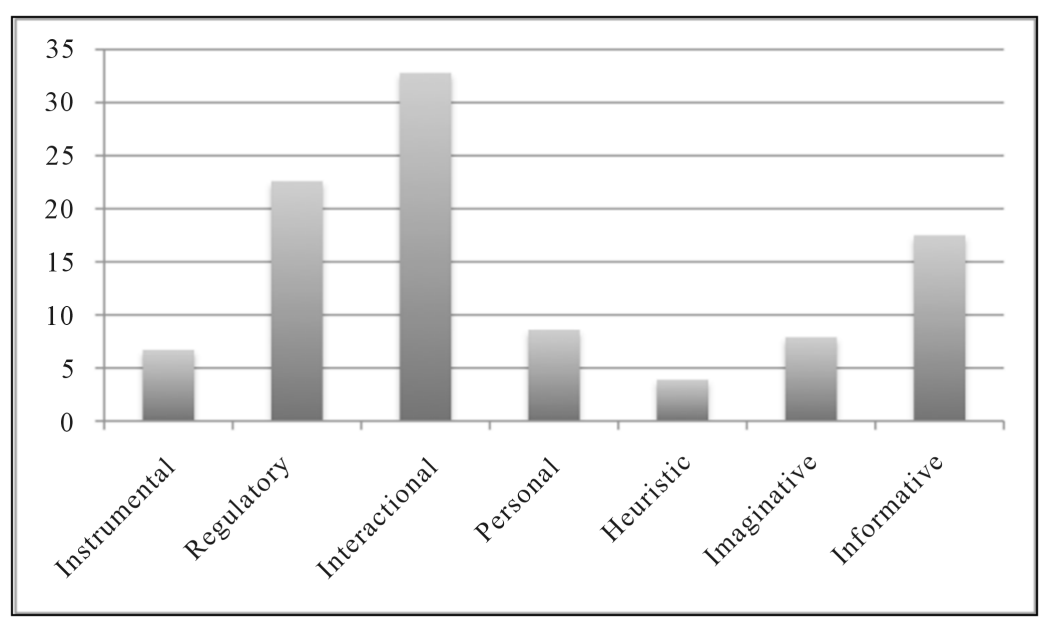

Figure 1. Language use with play partners.

In the beginning of her $4^{\text {th }}$ year, Ann independently demonstrated the use of both interactional and regulatory language functions with peers during play. In addition, teachers and teachers' assistants in the classroom encouraged Ann to engage in informative language functions. They did this by encouraging her to describe her play activities or by asking her personal questions about herself. Ann used language within the informative language function category when she had adult support during the beginning of her $4^{\text {th }}$ year. In comparison, when she was older ( 4 and 1/2 years old), Ann began to use language within the heuristic language function and imaginative language function categories.

Research Question 2: Does a native ASL Deaf child use of language vary with play partners?

Further analysis showed that Ann's language use varied depending on whom she was paired with in a play center. The variation was noted to vary with whether she was playing with a "Friend" or Other Peer". Recall, a Friends referred to three peers who are from deaf families and reported by the teacher as language peers, while Others Peers refer to the rest of the peers in class who are non-language peers.

Data found in Figure 2 showing the observed differences on how Ann used language with play partners (Friends and Other Peers) can be summarized as follows:

1) Regulatory function of language was reported high with both Friends (30\%) and Other Peers (20\%).

2) With Friends, she demonstrated mostly regulatory (30\%) and interactional functions (30\%)while with Other Peers it was mostly regulatory language (20\%) and personal language (17\&).

3) Interactional, informative and imaginative language functions occurred twice and some times more than twice as much with Friends, than with Other Peers.

4) Instrumental language (13\%) was more likely to be used with Other Peers than with Friends.

5) Heuristic language was rarely used with both Friends and Other Peers.

6) Personal language was similarly used with both Friends and Other Peers

Research Question 3: Does play context influence a native ASL Deaf child's use of language with play partners?

In the previous research question, Ann's language was observed to vary with play partners. Recall that Ann's classroom had ten play centers and the teacher was responsible for assigning students into the play centers. During the data analysis it was noted that Ann was rarely assigned in two play centers with Other Peers (large block play center and play cards center) and was never assigned in rice play center with Friends. These three play centers were omitted in the current analysis. Hence, Ann's language use with play partners in various play centers was limited to seven play centers, including Lego play, play dough, dramatic play, farm animal play, mini block play, geo boards, and puzzle centers. The current question explored if this variation in language use changed across various play centers within the classroom. Variation was shown in language use between Friends and Other Peers (see above).

In Figure 3, data shows how Ann used language in various play centers with Friends and Other Peers. The key findings related to Ann's use of language with Friends and Other Peers in various play centers within a classroom during the one-year period showed the following: 


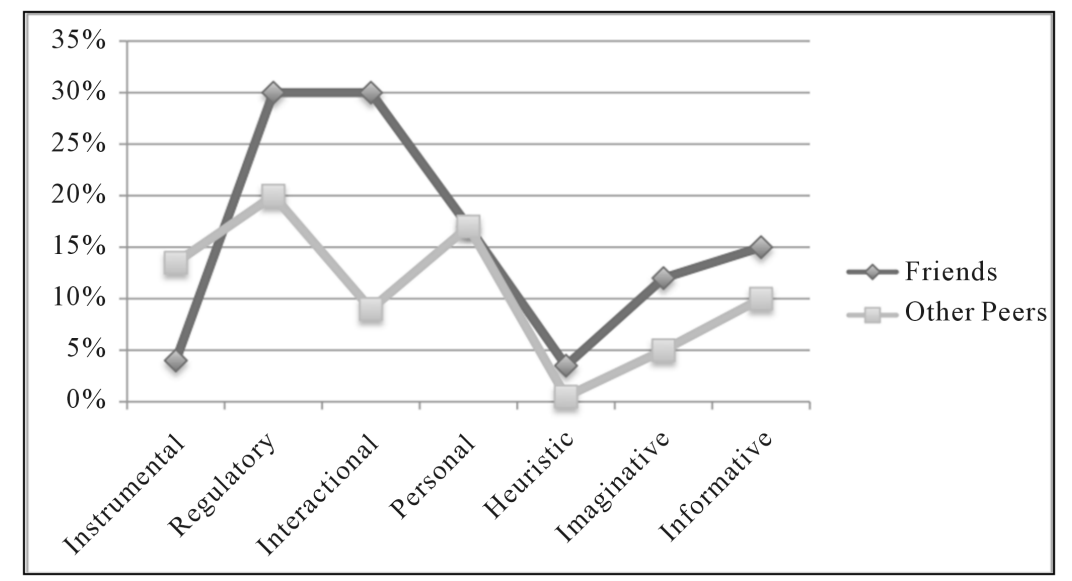

Figure 2. Language use by play partners: Friends and other peers.

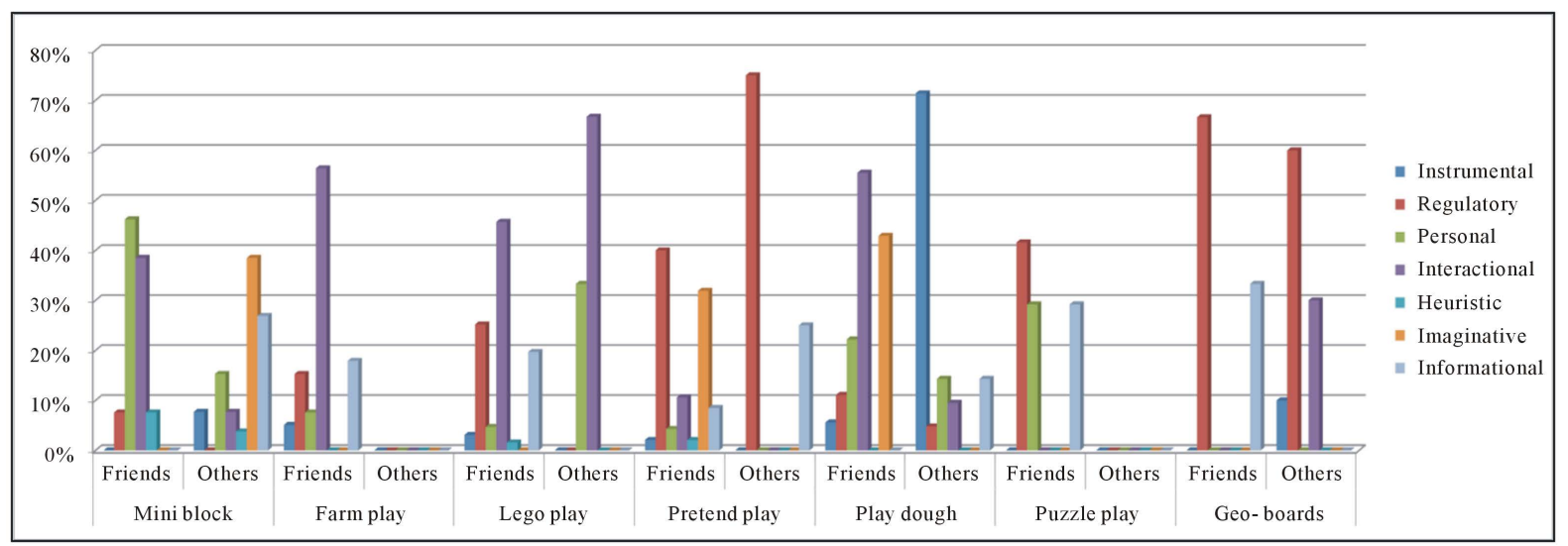

Figure 3. Language use by play partners: Friends and other peers.

1) Instrumental language function: Ann rarely demonstrated instrumental language function with Friends but it was significantly demonstrated in the play dough center with Other Peers.

2) Regulatory language: Regulatory language was mostly used in Geo board center and pretend play center with both Friends and Other Peers.

3) Interactional language: Interactional language appeared to be a dominant language function with Friends in the mini block center, farm play, Lego, and play dough. With Other Peers, Ann used interactional language mostly in Lego play (67\%) and Geo boards (30\%).

4) Personal language function: Personal language function was observed with Friends in mini block, play dough and puzzle play center and with Other Peers more in mini block and Lego play center.

5) Heuristic language function: Ann sparingly demonstrated heuristic language function with both Friends and Other Peers mostly in mini block play center.

6) Imaginative language function: Imaginative language function was observed used by Ann with both Friends and Other Peers in mini block and pretend play centers.

7) Informative Language: While playing with Friends, Ann was observed using informative language function in all play centers, except mini block play center. It was mainly used with Friends in Geo board and Puzzle Play. On the other hand, with Other Peers Ann was observed using informative language mostly in mini block play center and pretend play center.

Also, Figure 3 shows the seven language functions and in which play centers Ann was observed dominantly using the language function. From Figure 3 Ann demonstrated use of various language functions with both Friends and Other Peers mostly in mini block play and pretend play centers. In Geo-board play center, Puzzle play and Play dough center there was minimal language use with both Friends and Other Peers. 


\section{Discussions}

From this study, it appears that the choice of play partners and the type of play center is critical to the deaf child's language use during play. The deaf child, like any other child, changed her language use with the change of a conversation partner (Hoff, 2010; Shatz \& Gelman, 1973). The study showed how the deaf child's language varied depending on whether the play partner was a Friend or Other Peers. This is evident through the type of language functions demonstrated with the Friend (identified as language peer), and with Other Peers (identified as not language peer), during peer play interactions displayed over a year. These findings can be used to explain previous research findings on deaf children's play interactions as limited because the deaf child's language and that of the play partner was not considered (Mann, 1984; Esposito \& Koorland, 1989).

In addition, the findings in this study support previous studies whose findings show that language register used in children's play is influenced by play context (Girolametto, Weitzman, Lieshout, \& Duff, 2000; Gillen \& Hall, 2001; Isbell \& Raines, 1991). Language register refers to a variety of a language or a level of usage, as determined by degree of formality social context, purpose, and audience. Ann's language use was observed to vary not only with play partners but also with the play centers. In particular, in mini play center and pretend play center, she was observed to engage in various language functions with both Friends and Other Peers. Also, in some play centers certain language functions were neither observed with Friends nor Other Peers.

\section{Implication for Practice}

Early language access is important for a child's language and social development. In the current study, a possible argument for language use difference is that Ann and her Friends shared a common bond of early access to language through deaf parents. This allowed their ASL to be age appropriate; to attend to their language needs during play. On the other hand, Other Peers experienced delays in ASL acquisition up to school age and were at different levels of language competency to attend to their language needs during play. Early access to language enables children to demonstrate a variety of language functions, including those that support early literacy development.

In the current study, extended discourse was mostly observed between Ann and her Friends when she used informative language function and imaginative language function. Teachers need to facilitate this to occur between all children, including those with limited language development. Teachers can encourage the use of informative language function and imaginative language function by modeling it to students during play.

The preschool teacher may consider organizing the classroom setting by paying attention to play partners and play centers. Previous studies on peer play interaction have shown that having children play in the same play center does not assure interaction will occur (Brown \& Bergen, 2002; Sontag, 1997). Consequently, absence of peer interaction will lead to limited language use between peers.

In the current study it was observed that while Ann was playing with Other Peers, she demonstrated more language use than in other centers. These play centers included mini-block play and pretend play center. This called for the teacher to intentionality plan the play centers and assigning students to specific play centers. Following the findings of the current study the preschool teacher can intentionally purpose to plan and provide more opportunities in mini block play centers and pretend play centers during the school year. In addition, the preschool teacher can pair deaf children who are weak in ASL use with those who are strong in ASL, use in order to provide opportunity for peer support or scaffolding of language.

Teacher preparation programs play a significant role in teaching the characteristics of play and how to use play to scaffold language learning among bilingual students. In particular, teachers require knowledge and skills to support students who may not be proficient in the classroom language, in this case, ASL. Equipping teachers with ASL/English bilingual knowledge and strategies will enable them to understand how to support their students' language needs. Such knowledge empowers teachers to overcome the limitations of their individual classroom settings. Teachers should identify with students' diversity and embrace their important role in creating opportunities that will naturally promote the types of play behavior and play interactions that support ever-increasing language use. Currently, there is no teacher preparation program that focuses on Early Education for deaf children. Most of the teachers in preschool classrooms for deaf children have either been trained as deaf education teachers or they have attended early childhood education teacher preparation programs that focus on students in regular education programs. Consequently, teacher preparation in deaf early childhood education is a continuing area of need in the field of deaf education. 


\section{Conclusion}

This study documents how play partners and language use are closely associated. The child's play partner appeared to influence the child's language use and hence, influenced the child's pragmatic language observed and exercised during play. In providing a deaf child with a comparable language peer during play, this can be instrumental in supporting the development of a deaf child's pragmatic or conversational use of language. In addition, the current study identified the mini block play center and pretend play center as the play centers in which the deaf child demonstrated use of language for various functions with both language peers and non-language peers. Hence, these two play centers can be explored as possible play center to bridge the gap between deaf children with different language abilities and to make it possible to engage in pragmatic language use. This is especially true in the case of using peers with more advanced language levels to support or scaffold language learning during play interactions in the ASL/English bilingual classroom. The study and documentation of language use during play provides a support to language learning and language teaching with young deaf children in the preschool settings.

\section{References}

Allen, T. (1986). Patterns of Academic Achievement among Hearing Impaired Students: 1944 and 1983. In Karchmer (Ed.), Deaf Children in America (pp. 161-206). Boston: Little Brown.

Aukrust, V. G. (2004) Explanatory Discourse in Young Second Language Learners’ Peer Play. Discourse Studies, 6, 393412. http://dx.doi.org/10.1177/1461445604044296

Brackett, D., \& Henniges, M. (1976). Communicative Interaction of Preschool Hearing Impaired children in an integrated setting. The Volta Review, 78, 276-285.

Brown, M., \& Bergen, D. (2002). Play and Social Interaction of Children with Disabilities at Learning/Activity Centers in an Inclusive Preschool. Journal of Research in Childhood Education, 17, 26-37. http://dx.doi.org/10.1080/02568540209594996

Carpenter, R., Mastergeorge, A., \& Coggins, T. (1983). The Acquisition of Communicative Intentions in Infants Eight to Eighteen Months of Age. Language and Speech, 26, 101-116.

Cornelius, G. \& Hornett, D. (1990). Play behavior of Hearing-Impaired Kindergarten Children. American Annals of the Deaf, 135, 316-321.

Darbyshire, J. (1977). Play Patterns in Young Children with Impaired Hearing. Volta Review, 79, 19-26.

Dickinson, D., \& Tabors, P.T. (Eds.) (2001). Beginning Literacy with Language. Baltimore, MD: Brooks.

Doyle, A., Connolly, J., \& Rivest, L. (1980). The Effect of Playmate Familiarity on the Social Interactions of Young Children. Child Development, 51, 217-223.

Erting, C. J. (2003). Language and Literacy Development in Deaf Children: Implications of a Sociocultural Perspective. In: B. Bodner-Johnson, \& M. Sass-Lehrer (Eds.), The Young Deaf or Hard of Hearing Child: A Family-Centered Approach to Early Education (pp. 373-398). Baltimore: Brookes Publishing.

Esposito, B. G., \& Koorland, M. A. (1989). Play Behavior of Hearing Impaired Children: Integrated and Segregated Settings. Journal of Exceptional Children, 55, 412-419.

Gatty, J. (1990). The Effects of Deafness on Play in Four-Year-Old Boys. Unpublished Dissertation, Amherst, MA: University of Massachusetts.

Gerner de Garcia, B. (2003). Acquisition of English Literacy by Signing Deaf Children. Ponto de Vista: Revista de Educado e Processos Inclusivos, No. 5, 129-150.

Gillen, J., \& Hall, N. (2001). “Hiya, Mum!”: An Analysis of Pretence Telephone Play in a Nursery Setting. Early Years, 21, 15-24. http://dx.doi.org/10.1080/09575140123969

Girolametto, L., Weitzman, E., Van Lieshout, R., \& Duff, D. (2000). Directiveness in Teachers' Language Input to Toddlers and Preschoolers in Day Care. Journal of Speech, Language, and Hearing Research, 43, 1101-1114. http://dx.doi.org/10.1044/jslhr.4305.1101

Gregory, S., \& Mogford, K. (1983). The Development of Symbolic Playing Young Deaf Children. In D. Rogers, \& J. A. Sloboda (Eds.), The Acquisition of Symbolic Skills (pp. 221-231). New York: Springer.

Halliday, M. A. K. (1974). Explorations in the Functions of Language. London: Edward Arnold.

Halliday, M. A. K. (1975). Learning How to Mean: Explorations in the Development of Language. London: Edward Arnold. http://dx.doi.org/10.1016/b978-0-12-443701-2.50025-1 
Halliday, M. A. K. (1978). A Social-Functional Approach to Language. In M.A.K. Halliday (Ed.), Language as Social Semiotic (pp. 36-58). London: Edward Arnold.

Halliday, M. A. K. (1979). One Child's Protolanguage. In M. Bullowa (Ed.), Before Speech: The Beginning of Interpersonal Communication (pp. 171-190). Cambridge: Cambridge University Press.

Higginbotham, D., \& Baker, B. (1981). Social Participation and Cognitive Play Differences in Hearing Impaired and Normally Hearing Preschoolers. The Volta Review, 83, 135-149.

Hoff, E. (2003). The Specificity of Environmental Influence: Socioeconomic Status Affects Early Vocabulary Development via Maternal Speech. Child Development, 74, 1368-1378. http://dx.doi.org/10.1111/1467-8624.00612

Hoff, E. (2010). Context Effects on Young Children's Language Use: The Influence of Conversational Setting and Partner. First Language, 30, 461-472. http://dx.doi.org/10.1177/0142723710370525

Isbell, R. T., \& Raines, S. (1991). Young Children’s Oral Language Productions in Three Types of Play Centers. Journal of Research in Childhood Education, 5, 140-146. http://dx.doi.org/10.1080/02568549109594811

Johnson, R., Liddell, S., \& Erting, C. (1989). Unlocking the Curriculum: Principles for Achieving Access in Deaf Education. Washington DC: Gallaudet University.

Krestchmer, R. (1972). A Study to Assess the Play Activities and Gesture Output of Hearing Handicapped Preschool Children. Project No. 45-2109, Cincinnati Speech and Hearing Center: US Department of Health, Education, and Welfare, Office of Education, Bureau of the Handicapped.

Kuntze, M. (1998). Literacy and Deaf Children: The Language Question. Topics in Language Disorders, 18, 1-15. http://dx.doi.org/10.1097/00011363-199808000-00003

Lederberg, A. R., \& Spencer, P. E. (2001). Vocabulary Development of Young Deaf and Hard of Hearing Children. In M. D. Clark, M. Marschark, \& M. Karchmer (Eds.), Context, Cognition, and Deafness (pp. 73-92). Washington DC: Gallaudet University Press.

Mahshie, S. N. (1997). A First Language: Whose Choice Is It? Washington DC: Gallaudet University Laurent Clerc National Deaf Education Center. http://clerccenter.gallaudet.edu/documents/clerc/SI-AFirstLanguage.pdf

Mann, L. F. (1984). Play Behaviors of Deaf and Hearing Children. In D. S. Martin (Ed.), International Symposium on Cognition, Education, and Deafness (pp. 27-32). Washington DC: Gallaudet University Press.

Marshall, H., \& McCandless, B. (1957). A Study of Prediction of Social Behavior of Preschool Children. Child Development, 28, 149-159. http://dx.doi.org/10.2307/1125877

Mayberry, R. I. (2002). Cognitive Development of Deaf Children: The Interface of Language and Perception in Neuropsychology. In S. J. Segaolwitz, \& I. Rapin (Eds.), Handbook of Neuropsychology (2nd ed., Vol. 8, Part II, pp. 71-107). Amsterdam: Elsevier.

Meadow, K., Greenberg, M., Erting, C., \& Carmichael, H. (1981). Interactions of Deaf Mothers and Deaf Preschool Children: Comparisons with Three Other Groups of Deaf and Hearing Dads. American Annals of the Deaf, 126, 454-468. http://dx.doi.org/10.1353/aad.2012.1463

Miles, M. B., \& Huberman, A. M. (1994). Qualitative Data Analysis. Thousand Oaks, CA: Sage.

Mitchell, R. E., \& Karchmer, M. A. (2004). When Parents Are Deaf vs. Hard of Hearing: Patterns of Sign Use and School Placement of Deaf and Hard-of-Hearing Children. Journal of Deaf Studies \& Deaf Education, 9, 133-152. http://dx.doi.org/10.1093/deafed/enh017

Mitchell, R. E., \& Karchmer, M. A. (2005). Parental Hearing Status and Signing among Deaf and Hard of Hearing Students. Sign Language Studies, 5, 83-96. http://dx.doi.org/10.1353/sls.2005.0004

Moores, D. (2001). Educating the Deaf: Psychology, Principles, and Practices (5th ed.). Boston, MA: Houghton Mifflin Company.

Morford, J. P., \& Mayberry, R. I. (2000). A Reexamination of "Early Exposure” and Its Implications for Language Acquisition by Eye. In C. Chamberlain, J. P. Morford, \& R. I. Mayberry (Eds.), Language Acquisition by Eye (pp. 111-128). Mahwah, NJ: Lawrence Erlbaum Associates.

Musyoka, M. (2015). Understanding Indoor Play in Deaf Children: An Analysis of Play Behaviors. Psychology, 6, 10-19. http://dx.doi.org/10.4236/psych.2015.61002

Newport, E. L., \& Meier, R. P. (1985). The Acquisition of American Sign Language. In D. I. Slobin, (Ed.), The Cross-Linguistic Study of Language Acquisition (Vol. 1, pp. 881-938). Hillsdale, NJ: Lawrence Erlbaum Associates.

Olswang, L., Stoel-Gammon, C., Coggins, T., \& Carpenter, R. (1987). Assessing Prelinguistic and Early Linguistic Behaviors in Developmentally Young Children. Seattle, WA: University of Washington Press.

Pershey, M. G. (1994). Children's Awareness of Pragmatic Language Functions in Narrative Text. Dissertation Abstracts International, DA9434288. 
Pershey, M. G. (1997). Teaching Pragmatic Language Awareness as an Integral Aspect of Reading and Language Arts Instruction. Reading Horizons, 37, 299-314.

Roskos, K., \& Christie, J. (Eds.) (2000). Play and Literacy in Early Childhood: Research from Multiple Perspectives. Mahwah, NJ: Lawrence Erlbaum.

Schick, B., de Villiers, P. A., de Villiers, J. G., \& Hoffmeister, R. (2007). Language and Theory of Mind: A Study of Deaf Children. Child Development, 78, 376-396. http://dx.doi.org/10.1111/j.1467-8624.2007.01004.x

Schick, B., de Villiers, P., \& de Villiers, J. (2002). Theory of Mind: Language and Cognition in Deaf Children. Rockville, MD: ASHA Leader.

Schirmer, B. (1989). Relationship between Imaginative Play and Language Development in Hearing-Impaired Children. American Annals of the Deaf, 134, 219-222. http://dx.doi.org/10.1353/aad.2012.0609

Shatz, M., \& Gelman, R. (1973). The Development of Communication Skills: Modifications in the Speech of Young Children as a Function of Listener. Monographs of the Society for Research in Child Development, 38, 1-38. http://dx.doi.org/10.2307/1165783

Sontag, J. C. (1997). Contextual Factors Influencing the Sociability of Preschool Children with Disabilities in Integrated and Segregated Classrooms. Exceptional Children, 63, 389-404.

Spencer, P. E. (1993). A Descriptive Study of Play by Deaf and Hearing Infants. Washington DC: Gallaudet Research Institute.

http://www.eric.ed.gov/ERICWebPortal/custom/portlets/recordDetails/detailMini.jsp? nfpb=true\& \&ERICExtSearch Se archValue_0=ED385109\&ERICExtSearch_SearchType_0=no\&accno=ED385109

Spencer, P. E. (1996). The Association between Language and Symbolic Play at Two Years: Evidence from Deaf Toddlers Child Development, 67, 867-881. http://dx.doi.org/10.2307/1131866

Spencer, P. E. (2000). Looking without Listening: Is Audition a Prerequisite for Normal Development of Visual Attention during Infancy? Journal of Deaf Studies and Deaf Education, 5, 291-302. http://dx.doi.org/10.1093/deafed/5.4.291

Wiens, A. N., Molde, D. A., Holman, D. C., \& Matarazzo, J. D. (1966). Can Interview Interaction Measures Be Taken from Tape Recordings? Journal f Psychology, 63, 249-260. http://dx.doi.org/10.1080/00223980.1966.10543038

Woolfe, T., Herman, R., Roy, P., \& Woll, B. (2010). Early Vocabulary Development in Native Deaf Signers: A BSL Adaptation of the Communicative Development Inventories. Journal of Child Psychology and Psychiatry, 51, 322-331. http://dx.doi.org/10.1111/j.1469-7610.2009.02151.x

Yoshinaga-Itano, C., \& Stredler-Brown, A. (1992). Learning to Communicate: Babies with Hearing Impairments Make Their Needs Known. Volta Review, 94, 107-129. 